\title{
RESTRICTIONS ON THE RELIGIOUS JUDICIARYS' AUTHORITY AS A RESULT OF JUDICIAL POWER CONFLICT RULES
}

\author{
Rahadi Wasi Bintoro \\ Law Faculty of Jenderal Soedirman University \\ E-mail: rahadiwasibintoro@gmail.com
}

\begin{abstract}
The new authorities of religious courts, particularly in Economics Sharia field still collide with other rules. This writing intends to identify the rules conflict that exist. Based on the analysis, can be identified the rule conflict relating to the authority of the judge occurs on the peace effort. Rules of conflict regarding peace with instrument PerMA No.1 year 2008 can be accessed by using the principle of lex superior derogat legi law priori, whereas with regard to the authority prosecuting Sharia Board of arbitration verdict temporarily can use the verdict of the Supreme Court of Cassation Number 56/PK/AG/2011, however this is still not final because we are not wedded to the binding force principle of precedent. The next rule of conflict is related with judgement authority to the bankruptcy matter. On this occasion, the author gives suggestions to immediately syncronize authorities prosecutes' rules, so it can give birth to legal certainty.
\end{abstract}

Key words: authority to prosecute, peace, bankruptcy

\begin{abstract}
Abstrak
Kewenangan baru Peradilan Agama, khususnya dlam bidang ekonomi syariah, ternyata masih berbenturan dengan aturan lainya. Tulisan ini bermaksud untuk mengidentifikasi konflik aturan yang ada. Berdasarkan analisis, dapat diidentifikasi konflik aturan berkaitan dengan kewenangan mengadili terjadi pada upaya perdamaian. Konflik aturan mengenai perdamaian dengan instrumen PerMA No. 1 Tahun 2008 dapat didekati dengan menggunakan asas hukum lex superior derogat legi priori, sedangkan berkaitan dengan kewenangan mengadili putusan badan arbitrase syariah untuk sementara ini dapat digunakan Putusan Kasasi Mahkamah Agung Nomor56/PK/AG/2011, namun demikian ini masih belum final karena kita tidak menganut asas the binding force of precedent. Konflik aturan berikutnya adalah berkaitan dengan kewenangan mengadili perkara kepailitan. Pada kesempatan ini, penulis memberikan saran untuk segera dilakukan sinkronisasi aturan kewenangan mengadili, sehingga dapat melahirkan kepastian hukum.
\end{abstract}

Kata kunci: kewenangan mengadili, perdamaian, kepailitan

\section{Introduction}

The communitys' social life which increase more complex, particularly in Islamic economy field grow rapidly In Indonesia ${ }^{1}$ even in the world. ${ }^{2}$ Rapid development of Islamic economy is the managed by the Government by doing a

\footnotetext{
Eman Suparman, "Perkembangan Doktrin Penyelesaian Sengketa di Indonesia", Jurnal Penegakan Hukum, Vol. 3 No. 2, July 2006, Bandung: Law Faculty of Padjadjaran University, page 21-35; see also Muhammad Syafi'i Antonio, "Membangun Ekonomi Islam di Indonesia", Varia Peradilan, Year XXI No. 245 April 2006, Jakarta: IKAHI, page 25; and Ali Mansyur, "Aspek Hukum Perbankan Syariah dan Implementasinya di Indonesia", Jurnal Dinamika Hukum, Vol. 11 Special Edition, 2011, Purwokerto, Law Faculty of Jenderal Soedirman University, page 69
}

make changes to the Act No. 7 of 1989 concerning religious courts through Act No. 3 of 2006 and Act No. 50 of 2009.

Fundamental changes, in particular with regard to the judicial authorities of the religion was not followed by harmonization of regula-

\footnotetext{
Mehmet Asutay, "Conceptualisation Of The Second Best Solution In Overcoming The Social Failure Of Islamic Banking And Finance: Examining The Overpowering Of Homoislamicus By Homoeconomicus", IIUM Journal of Economics and Managemen, Vol. 15, No. 2, 2007, Selangor: The International Islamic University Malaysia, page 168; see also M. Raquibuz Zaman and Hormoz Movassaghi, Islamic Banking A Performance Analysis “, The Journal of Global Business, Vol. 12, No. 22, Spring 2001, page 38.
} 
tory legislation in other fields. Keep in mind, that the authority owned by religious courts are increase more complex, particularly with Shari'ah pavements' economic authorities. In Islamic economy field, such as in bankruptcy areas, authorities resolve the dispute became public justice domain. How if it happens to a legal entity based on sharia principles? For whose the authority goes? In addition, if the dispute is resolved in non litigation, such as arbitration, who break the annulment of the award (the national Syariah Board of arbitration), religious courts or public justice? The questions arose because of the authority-owned religious courts areas are not coupled with harmonization of other regulations relating to the judicial authorities of the Religion. The existing rules, conflict in time will only lead to legal uncertainty. This paper tries to identify the conflict rules relating to judicial authority of religion, with the hope this writing can be one of the inputs for the refinement, in particular with regard to the judicial authorities of the religion.

\section{Discussion}

\section{Peaceful resolution of disputes}

There is a fundamental change in the religious courts through the last two laws were inspired because the previous laws were no longer in compliance with the development needs of the legal community and the life attempt according to the 1945 constitution of Indonesia. Through this wider authority, at least not to be expected that things that go into religious courts would increasingly complex. However, after so many years pass looks that matter in the field of marriage is still a favorite matter handled by religious courts.

Dispute resolution itself can be resolved through litigation and non litigation. Litigation is dispute resolution which is done through the courts. In this case the Parties utilizing the judge as an independent party to check and drop the

\footnotetext{
3 See Rahadi Wasi Bintoro, "Implementasi Mediasi Litigasi di Yurisdiksi Pengadilan Negeri Purwokerto", Jurnal Dinamika Hukum, Vol. 14 No. 1, January 2014, Purwokerto: Law Faculty of Jenderal Soedirman University, page 14.
}

verdict that based on the principle of fairness. Non litigation itself is an out of court dispute resolution by making use mediation of institution, conciliation, arbitration or negotiation, the purpose of the dispute resolution mechanism in non litigation is peace. ${ }^{3}$ Basically settlement the non completion of the litigation was chosen by the parties because of the litigation process takes quite a long and convoluted process, ${ }^{4}$ besides little things that can be done with the way of peace on the Court.

The Supreme Court (MA) observing this condition, then in 2003 was issued in the Supreme Court Ordinance No. 2 of 2003 which is in the process being replaced by Supreme Court Rule No. 1 in 2008 about procedure of the mediation procedure in court. This Rules of Supreme Court other than apply to matters civil litigation in the District Court, also apply to the matter in the courts of religion. The ontological basis is law equation that used, because it is based on the provisions of article 55 of ACT No. 7 of 1989 concerning religious courts, the law applicable at the Justice Court in the event of civil libility law is applicable to the Justice Court in General, except where specifically regulated in this law.

The sentence "except where specifically regulated in this law" may be interpreted that Act No. 7 of 1989 implemented a different special law with civil law that is in the public justice. For example in the fields of marriage divorce happens only when there is adivorce, from husband or his representative. Included in this is an attempt to reconcile the two sides.

An attempt to reconcile, with the help of judges, specifically in the case of divorce, actually has been set in Act No. 7 of 1989, in which the husband and wife should come personally, unless one of the parties is housed in a residence abroad, and unable to come personally facing can be represented by his power which is specifically delegated to it (article 86 paragraph (2)). In addition, in the event of divorce for rea-

\footnotetext{
4 Lihat Novita Riama, “Analisis Yuridis Terhadap Implementasi Asas Peradilan Sederhana, Cepat dan Biaya Ringan dalam Penyelesaian Perkara Perdata", Jurnal Nestor Magister Hukum, Vol. 2 No. 3, Tahun 2013, Pontianak: Universitas Tanjungpura Pontianak, page 14
} 
sons of syiqaq, then the Court after hearing of witnesses about the nature of the dispute between husband and wife can lift one or more of the families of each of the parties or other persons to be hakam (article 76 paragraph (2)). Hakam is the man who established the family courts of the husband or the wife's family or others to seek dispute resolution attempt against syiqaq, which of course is the output is the peace.

Supreme Court rule No. 1/2008 outline that peace with the mediation absolutely mandatory. Thus all things should resolved through mediation, as outlined article 2 paragraph (2) of the Supreme Court Ordinance No. 1 of 2008, that any resolution of the matter submitted to the Court, obliged first attended the mediation process. Whereas according to Article 18 paragraph (2), the Court should examine new matters through ordinary civil law process, if the mediation process fails to produce agreement. Before there was a written statement from the mediators stated the mediation process failed to reach a peace agreement, a settlement through the litigation process should not be done. The mediation process itself is done through meetings and negotiations the parties litigant assisted directly by the mediator actively, start from beginning to end of the process.

The peace arrangements in the Supreme Court Ordinance No. 1 year 2008 in particular, especially in the case of divorce, very different. This absolutely raises the overlap. However keep in mind regarding the principles and regulations: ${ }^{5}$ first, the principle of lex superior derogat legi inferior, stressed that the legislationis more higher override existing laws and regulations under it; secondly, the principle of lex specialis derogat legi generalis, who stresses that more specific regulations over ride the common regulations; third, the principle of lex posterior derogat legi priori, this principle emphasizes that the new legislation over ride laws the oldinvitation; fourth, the principle of legislation should not be retroactive (non-retroactive). Overlap ar- rangements regarding the peace between Supreme Court Rule No. 1 year 2008 by Act No. 7 year 1989, according to the author can be solved using the principle of lex superior derogat legi inferior, having regard to Act No. 12 year 2011 about the layout order of National legislation.

Hierarchy of legislation of Indonesia are as follows: first, the constitution of 1945; second, TAP MPR; third, the legislation/Regulation on Substitute legislation; fourth, government regulations; fifth, The Regulation of the President; sixth, the seventh province, local regulations, applicable local County/City (article 7 paragraph (1)), then Article 8 paragraph (1) that is:

This type of Legislation other than as stipulated in article 7 paragraph (1) covers the rules set by people's Consultative Assembly, the House of representatives, the regional representative Council, Supreme Court, Constitutional Court, the Judicial Commission, Financial Examiners, Indonesian Bank, Minister, agencies, institution, or Commission level established by law or by order of the Government legislation, House of representatives, Governor of the Provinces, Representatives of Regional District/City, Regent/Mayor, head of the village or the level.

Supreme Court rule no. 1 year 2008 itself was born as a result of the implementation of section 130 of HIR that impressed formalistics only, resulting in a civil lawsuit proceedings continue until the level of the Supreme Court, resulting in a build-up of the matter in the Supreme Court. Thus the Supreme Court Ordinance was derivative from HIR that in fact on par with the law. In this case it applies the principle of lex superior derogat legi inferior. Thus not all things in religious courts using PerMA No. 1 year 2008.

Dispute resolution outside the Court also aims to create a peace. In relation to the settlement with the fundamental principles of Sharia, in Indonesia there is already a national Sharia Board of arbitration. Act No. 3 year 2006 Article 48 subparagraph (i) and article 55 paragraph (1) of ACT No. 21 year 2008 about Islamic banking

\footnotetext{
5 See Marwan Mas, "Mengurai Putusan Pembatalan UU No. 45 Tahun 1999", Jurnal Konstitusi, Vol. 1 No. 2, December 2004, Jakarta: Mahkamah Konstitusi RI, page 29
} 
has given authority to the religious Court to check, disconnect and resolve the matter in the first level between people who are predominantly in the field of Islamic economy, especially in Islamic banking disputes. However, this power is limited by article 55 paragraph (2) of ACT No. 21 year 2008 which set out that the parties have their own dispute settlement guarantee, then dispute resolution conducted in accordance with the contents of the contract/agreement, that isi with a choice of dispute resolution through discussion, negotiation, mediation, conciliation or arbitration (National Sharia Board of arbitration).

In 2013, the explanation of article 55 paragraph (2) of ACT No. 21 year 2008 was declared by the Constitutional Court doesn't have the force of law through binding ruling of the Constitutional Court No. 93/PUU-X/2012. The provisions of article 55 paragraph (2) of ACT No. 21 year 2008 set that dispute resolution outside the religious courts were resolved in accordance with the contents of the contract agreement. This provision in Article 55 paragraph (2) the settlement outside the religious courts can be resolved through the deliberations, banking mediation, the national Shariah Board of arbitration (Basyarnas) or other arbitration institutions; and/or through the courts in the Public Justice environment. Explanation of article 55 paragraph (2), give rise to overlapping of authority between judge religious courts with Public Justice, the parties to the agreement agree on there solution of disputes in Public Justice. Its own constitutional court holds that

“...The option of dispute resolution (choice of forum) to resolve disputes in Islamic banking as mentioned in the explanation of Article 55 paragraph (2) of the Act a quo will ultimately lead to the overlapping of authorities to prosecute because there are two courts which granted authority to resolve the dispute banking sharia Law while the other (Religious Courts Law) expressly stated that the religious courts..."

\footnotetext{
6 Andi Tenri Soraya, "Basyarnas Sebagai Lembaga Alternatif Penyelesaian Sengketa Bisnis Syariah”, Analisys Journal,
}

Consideration of the judges can be interpreted that all contract/agreement conflicted with the authority to prosecute owned by religious courts, then it's unconstitutional.

The problem appear when the dispute is resolved in the arbitration institution, the national Shariah Board of arbitration, who is authorized to execute? Or in case there are objections and intend to file an annulment of the decision of a Board of arbitration over the Sharia, to the courts where these objections must be filed? This is a problem because the Constitutional Court's verdict can only be applied on Act No. 21 year 2008.

Based on article 59 paragraph (3) of ACT No. 48 year 2009 about the powers of the Judiciary Article 61 of ACT No. 30 year 1999 regarding arbitration and alternative dispute resolution, against the execution verdict of the National Sharia Board of arbitration was carried out on the orders of the District Court Chairman, upon the petition of either party to the dispute (article 59 paragraph (3) of ACT No. 48 year 2009 about the Power of Justice Article 61 of law No. 30 year 1999 on arbitration and alternative dispute resolution). This authorities prosecute then gave rise to a debate ${ }^{6}$ as a result of the Supreme Court Circulars No. 8 year 2008 about the execution of the decision of a Board of arbitration which Sharia confirmed that:

In case the ruling of the Shariah Board Arbitration is not executed voluntarily, then the verdict was carried out on the orders of the Chairman of the court authorities over the petition of either party to the dispute and therefore in accordance with article 49 Lawnumber 7 year 1989 as amended by no. 32006 Religious Courts also served and authorized checking, decide and resolve matters in the field of Islamic economy, then the Chairman of the Court of religious authorities ordered the implementation of Shariah Board of arbitration verdict".

But after that in $2010 \mathrm{MA}$ again issued circulars, namely Circulars of the Supreme Court No. 8 year 2010 confirmed:

Makasar: Post-Graduated of Hassanudin University, page 175 
Based on article 59 paragraph (3) of Act No. 48 year 2009 about the explanation Power of Justice and determined that, in the event that the parties are not implementing the ruling of the arbitration (including arbitration Shari'ah) on a voluntary basis, the verdict was carried out on the orders of the Chairman the District Court upon petitionof one of the parties to the dispute...

With the respect of to the matters above, then was told to the people, that counted since the enactment of Act No. 48 year 2009 about the powers of the Judiciary, Supreme Court Circulars number 08 year 2008 about the execution verdict of the Shariah Board of arbitration based on article 59 paragraph (3) of Act No. 48 in 2009 about the powers of the judiciary and the explanation, otherwise not applicable.

The last circular letter is then made as one of the "basic" by the judges which break on the review on the matter Number 56/PK/AG/2011 who back to affirm that religious courts are not authorized to inspect, judge and break the National Syariah Board of arbitration verdict.

Circulars are certainly not legislation as maintain in Act No. 12 year 2011, so it can be ruled out given remember that is not a source of law. But interesting when debate emerged as the result of a conflict between the rules, Act No. 3 year 2006, Act No. 21 year 2008 and Act No. 30 year 1999 .

In this case, the principle of the law means that the basis of lex specialis derogat legi generalis. Act No. 3 year 2006 set that the dispute between a Muslim person/legal entities subject to sharia principles in economics Sharia religious becomes courts authority, while Act No. 9 year 2008 give the limitation to the the judicial authorities of the religion that is the parties have made an agreement that the dispute will be conducted out of Court (such as throughthe national Syariah Board of arbitration), the religious courts are not authorized to examine the matter.

Regarding to dispute resolution outside the religious courts, Act No. 30 year 1999 regulates that the cancellations and the execution of the ruling of the arbitration presented to the
District Court (District Court is the scope of the jurisdiction of the judiciary). In this case there is the tangent point on the Act No. 3 of 2006 with Act No. 30 of 1999 , but later when approached by the principle of lex specialis derogat legi generalis, then the question arises, which specialists (Special) and which is the generalist (General). Regardless of that question, the ruling of the Supreme Court of Cassation dropped the number 56/PK/AG/2011 provides a new legal basis that religious courts are not authorized to inspect, judge and decided above Shariah Board of arbitration verdict, but whether the judge's verdict will be followed by other judges when similar things break? Because in principle we do not adhere to the principle of the binding force of precedent. Who knows, through a more deep analysis, without simply using circular letter as a basis for taking the conclusion against the authority of religious courts, later there was another judge who gave a different verdict with the verdict of the Supreme Court of Cassation Number 56/PK/AG/ 2011. At least in the meantime, the basic law is the Supreme Court of Cassation Ruling Number 56/PK/AG/2011.

\section{Authority To Adjudicate Insolvency Matters}

Explanation of article 49 (i) Act No. 3 year 2006 mentions that act or business activities are carried out according to Islamic principles, among others, include: Islamic banks, Islamic microfinance institutions, insurance, reinsurance, Islamic Shariah, Shariah-compliant mutual funds, bonds and Shariah-compliant securities Shariah compliant securities, a medium-sized futures Sharia, Islamic financing, Islamic pawn shops, Islamic financial institution pension funds, syariah business. Understanding of the principles of Sharia itself can be found in article 1 of the number 13 Act No. 10 of 1998, namely the rules of Islamic law based on the agreements between banks with another party for a funds and storage or financing activities, or other activities are stated in accordance with Sharia.

In carrying out the economic activities of the Sharia, very possible subject of law (or legal entity) are not able to carry out their obligati- 
ons, such as doing no liability for loans/credit proposed, either from the bank, capital investment, the issuance of bondsor other means is allowed, which in time give rise to many problems of settlement of debts in the community. In this case the bankruptcy happen according to Article 1 point 1 of Act No. 37 year 2004 about bankruptcy and suspension of payment Debts formulated as General confiscation over all the wealth the debtor discharged the management and settlement done by the Curator under the supervision of a supervisory Judge.

Based on law No. 37 year 2004, Court who authorized bankruptcy is the Commerce Court was the jurisdiction of public justice. Does this also include the limitations against the authorities prosecute bankruptcymatters to the religious courts, considering law No. 37 of 2004 already asserted, that bankruptcy court of its commerce becomes that in fact is under of the jurisdiction public justice. On the other hand, is the religious courts of Justice for people whose muslim people (article 1 (1) of Act No. 50 year 2009).

In this case, the judiciary is one of the Religious institutions of the judiciary power who checking, decided and prosecute cases for a Muslim justice seekers are then referred to as the principle oflslamic personality. Basic Islamic Personality is not only attached on the subject of laws shaped people or subjects of a Muslim law only. ${ }^{7}$ This can be seen in the explanation Section 49 of Act No. 3 year 2006, the phrase "a Muslim" mean in this case include the person or legal entity on its own self voluntarily subjecting it to Islamic law on matters of judicial authority into the Religion.

Layout of one's Islamic personality principle is based on a factor of formyl without questioning the quality of the Islamic. As for the notion of Islamic personality this is the Agency of Islamic law that exist in the legal system in Indone-

\footnotetext{
Sri Suwastini, “Kompetensi Absolut Pengadilan Agama dalam Menangani Perkara Ekonomi Syariah Di Pengadilan Agama Pontianak", Nestor Journal, Vol. 1, No. 12014 , Pontianak: Law Post-Graduate Program of Tanjungpura University, page 4; see also Liliek Kamilah, "Mediasi sebagai Salah Satu Bentuk Penyelesaian Sengketa di Pengadilan Agama”, Perspective, Vol. XV No. 1, January Edition,
}

sia. ${ }^{8}$ The agency of Islamic law that are in law No. 3 year 2006 can be classified into four (4) categories. First, the legal entities that are established on the basis of the provisions of Islamic law, such as the agency of the Amil Zakat, Amil Zakat, Baitul Maal, Nadzir Waqaf and so on; second, the legal entities within the economy, such as Islamic banking Shariah, Islamic pawn shops and so on as mentioned in article 49 the letter; third, the legal entities owned by Muslims; fourth, other legal entities (legal entities) who are doing business or business activities by using sharia principles. Based on this description, then the principle of Islamic personality attached in matter as a basis for the determination of judicial power is Religion, not attached to the parties to the dispute.

The arrangements concerning the authority examining the matter bankruptcy resulted in a conflict of authority between judge religious courts with Judicial Public financingor implementation, if debts are implemented using sharia principles. In the event of conflict of rules then it should be approached with the basic law. At this level, the legal basis that can be used is the lex derogat legi generali specialists, but which of the two aforementioned laws are specific and common? To answer this question of course requires a through review to get to know the basic ontological second Act, so tha it can be known where the rules are common and where the rules that Special. If this authority belongs to the religious courts, of course this device be a burden on religious courts to do management human resources, considering matters relating to Islamic Economics have complexity which is not inferior to other fields in matters such as marriage.

\section{Closing}

Conclusion
Year 2010, Surabaya, Law Faculty of Wijaya Kusuma University, page 50 .

8 Ramlan Yusuf Rangkuti, "Sistem Penyelesaian Sengketa Ekonomi Islam: Instrumen Penting bagi Konsep Ekonomi Islam Mendatang", Asy-Syir'ah-Journal Legal and Syariah Law, Vol. 45 No. 2, July-December 2011, Yogyakarta, Syariah and Law Faculty of Sunan Kalijaga Islamic State University, page 1446-1447. 
Devolution authorities checking, decided and resolve the matter of Sharia economic to religious courts turn out to date still leaves a polemic, not only among academics andlegal practitioners, but also practitioners in the field of Islamic economy, particularly in the fields of banking and financing institutions. This is due to the settings on the economics of the sharia is not elaborate as the authority of the courts of other religions, such as marriage. When Sharia economy including complex problems and it is not easy, and is growing very rapidly, so that it can open spaces as well as allowing anyone can involved in it.

\section{Suggestion}

On this opportunity the author submits recommendations to make immediate sync rules, relating to the authority of the judge. The synchronization and harmonization of these rules can be done by making changes to the rules or else do review against an existing rule, then analyzed by using the legal principles that apply.

\section{Bibliography}

Antonio, Muhammad Syafi'i. "Membangun Ekonomi Islam di Indonesia". Varia Peradilan, Year XXI No. 245 April 2006. Jakarta: IKAHI;

Asutay, Mehmet. "Conceptualisation Of The Second Best Solution In Overcoming The Social Failure Of Islamic Banking And Finance: Examining The Overpowering Of Homoislamicus By Homoeconomicus". IIUM Journal of Economics and Managemen, Vol. 15. No. 2. 2007. Selangor: The International Islamic University Malaysia;

Bintoro, Rahadi Wasi. "Implementasi Mediasi Litigasi di Yurisdiksi Pengadilan Negeri Purwokerto". Jurnal Dinamika Hukum, Vol. 14 No. 1, January 2014. Purwokerto: Law Faculty of Jenderal Soedirman University;

Kamilah, Liliek. "Mediasi Sebagai Salah Satu Bentuk Penyelesaian Sengketa Di Pengadilan Agama". Perspektif, Vol. XV No. 1. January 2010. Surabaya: Law Faculty of Wijaya Kusuma Universitas;

Mansyur, Ali. "Aspek Hukum Perbankan Syariah dan Implementasinya di Indonesia". Jurnal Dinamika Hukum, Vol. 11 Special Edi- tion. 2011. Purwokerto Law Faculty of Jenderal Soedirman University;

Mas, Marwan. "Mengurai Putusan Pembatalan UU No. 45 Tahun 1999". Jurnal Konstitusi, Vol. 1 No. 2. December 2004. Jakarta: Mahkamah Konstitusi RI;

Rangkuti, Ramlan Yusuf. "Sistem Penyelesaian Sengketa Ekonomi Islam: Instrumen Penting bagi Konsep Ekonomi Islam Mendatang". Asy-Syir'ah - Jurnal Ilmu Syariah dan Hukum, Vol. 45 No. 2. July-December 2011. Yogyakarta. Law and Syariah Faculty Sunan Kalijaga Islamic State University;

Riama, Novita. "Analisis Yuridis Terhadap Implementasi Asas Peradilan Sederhana. Cepat Dan Biaya Ringan Dalam Penyelesaian Perkara Perdata". Journal of Nestor Law Magister, Vol. 2 No. 3. Year 2013. Pontianak: Tanjungpura Pontianak University;

Soraya, Andi Tenri. "Basyarnas Sebagai Lembaga Alternatif Penyelesaian Sengketa Bisnis Syariah". Journal of Analysis. Makasar: Post-Graduate of Hassanudin University;

Superman, Eman. "Perkembangan Doktrin Penyelesaian Sengketa di Indonesia". Jurnal Penegakan Hukum, Vol. 3 No. 2 July 2006. Bandung: Law Faculty of Padjadjaran University;

Suwastini, Sri. "Kompetensi Absolut Pengadilan Agama Dalam Menangani Perkara Ekonomi Syariah Di Pengadilan Agama Pontianak". Jurnal Nestor, Vol. 1. No. 1 2014. Pontianak: Law Post-graduate Program Tanjungpura University;

Zaman, M. Raquibuz and Hormoz Movassaghi. Islamic Banking A Performance Analysis “. The Journal of Global Business . Vol. 12. No. 22. Spring 2001. 